\title{
Internal Control And Organizational Culture in the Improvement of Managerial Performance
}

\author{
Rukmi Juwita \\ witawilanggana@rocketmail.com \\ Mutimmatul Adzkhiyah \\ Politeknik Pos Indonesia
}

\begin{abstract}
This research aimed to measure the influence of internal control and organizational culture in managerial performance. Data were obtained through questionnaires with sample of 46 from 84 SKPD in Banyumas Regency using purposive sampling technique. Data processing used is multiple linear regressions. The results showed that internal control and organizational culture simultaniously had a significant effect to managerial performance of government. Partially, internal control had significant effect while organizational culture had no significant effect on managerial performance of government. The implementation of internal control and organizational culture was good. Achievement of good managerial performance required good internal control to provide reasonable assurance on the achievement of organizational goals through effective and efficient activities, reliability of financial reporting, security of state assets and compliance with laws and regulations. Organizational culture became another factor that could improve managerial performance through fundamental values and passion in managing the organization.
\end{abstract}

Keywords: internal control, organizational culture, government managerial performance, banyumas regency government, $S K P D$

\section{INTRODUCTION}

Performance is the result of work achieved by employees in carrying out the tasks and jobs that come from the organization. The performance of the company and everyone is dependent on the managerial ability of the management in leading all workers, coordinating all their activities, and creating a conducive working climate. According to a research by Hazmi \& Zuarni (2012), managerial performance is one of the factors that can increase organizational effectiveness.

The 2008 Government Regulation no. 60 confirmed by the 2010 Regent Regulation No. 64 stated that the internal control system is an integral process in actions and activities undertaken continuously by the leaders and all employees to provide reasonable assurance on the achievement of organizational goals through effective and efficient activities, the reliability of reporting finance, security of state assets, compliance with laws and regulations.

One very effective model in improving the quality of a company or organization is Malcolm Baldrige's criteria for performance excellence; it has seven performance management criteria that are basically a number of questions about fundamental aspects of organizational management in the context of achieving superior performance. The seven criteria are: (1) Leadership, (2) Strategic planning, (3) Customer and public service, (4) Analysis measurement, (5) Application of science/knowledge in management, (6) Human resource empowerment, (7) Management process, and (8) Organizational result.

Achievement of good managerial performance requires a good internal control as well. Internal Control by Indonesian Institute of Accountants (IAI : 2015) is a system that includes all the methods and provisions that are organized in a company to protect their property, check the accuracy and reliability of accounting data and improve business efficiency.

Local government agencies have their own control or regulation for every employee and local government implementer serving the community. The government's internal control in every institution is necessary to prevent fraud in every service performed by employees in government agencies. The rules and codes of internal 
controls may be written or unwritten to be obeyed by every government employee.

Banyumas Regency Government conducts control activities based on the 2010 Regent Regulation no. 64 concerning the implementation of government internal control system within the government of Banyumas Regency based on the 2008 Government Regulation no. 60 on Government Internal Control System consists of five elements of internal control system, namely: 1. control environment, 2. risk assessment, 3. control activities, 4. information and communication, and 5. monitoring internal control. The regulation also has the purpose of internal control system that is to achieve effectiveness, efficiency, transparency and accountable state financial management.

The Government of Banyumas Regency in 2015 quoted from the government website www. banyumaskab.go.id dated 5 January 2016 states that Banyumas Regency becomes a regency with a significant economic growth of $7.10 \%$, higher than the economic growth of Central Java province which only reached $6.48 \%$. This is proved by the inflation of November 2015 which is the lowest among six pilot cities in Central Java Province namely Cilacap Regency with an inflation rate of $0.20 \%$, Kudus by $0.21 \%$, Surakarta by $0.32 \%$, Semarang by $0.21 \%$, Tegal by $0.24 \%$ and Banyumas by $0.16 \%$.

The significant economic growth in Banyumas Regency in 2015 and the increased performance throughout 2015 showed and ressulted in progress and achievement in various fields. Among the achievements of Banyumas district government are the audits of 2014 financial statements with Unqualified status, Adipura award and Wahana Tata Nugraha (WTN) award. The above have been described as one of the outcomes of internal controls demonstrated by the government of Banyumas Regency in managing government activities during 2015.

Internal controls that function effectively can support the achievement of organizational goals (Doyle, et al., 2007; Petrovis, et.al. 2010), then internal control must be implemented inherent with the operational activities of the organization and being part of the organizational culture, able to respond fast on risks arising in business execution derived from factors within the organization and changes in the operating environment and includes procedures to report promptly on significant weaknesses found and corrective actions taken to the management level who are interested. (Kurniawan, 2015: 112). Meanwhile, according to Jianfeileng and Zhao (2013) a better internal control system will be more likely to benefit from corporate activities and create more value for the company and shareholders.

In addition to internal control, organizational culture is also another factor affecting managerial performance in government (Testa and Sipe, 2013). Moreover, organizational culture becomes a marker or characteristic of an organization for society. Understanding organizational culture itself is a longlasting habit and is used and applied in the life of work activities as one of the drivers to improve the quality of work of employees and management company. It is supported from various sources stating that organizational culture has a strong relationship with organizational performance management.

The phenomenon of organizational culture also occurs within the scope of the government of Banyumas Regency which is the use of agate trends in 2015, the use of custom clothing, the use of Banyumas regional language that is penginyongan language. This indicates Banyumas Regency government is trying to preserve the cultural richness that is owned to avoid extinction and make the distinctive characteristics of the government of Banyumas Regency.

To examine organizational culture, the indicators of organizational culture of Stephen P Robbins (2006) will also be included: 1 . individual initiative, 2 . tolerance to risky action, 3. direction, 4. integrity, 5. management support, 6. control, 7. identity, 8. reward system, 9. tolerance to conflict, and 10. communication pattern.

Based on Nasir's and Oktari's (2011) study, internal control variable has positive and significant influence on the performance of government agency. While the results of research by Devi et.al. (2015) states that organizational culture both simultaneously and partially has a positive influence on employee performance. With these two studies, it is suspected that internal control and organizational culture have a significant influence on managerial performance. Thus, based on the above description, a hypothesis can be formulated that there is a significant simultaneously influence of internal control and organizational culture on managerial performance of Banyumas Regency government.

Andriyanto's (2013), Nasir's \& Oktari's (2011) research showed that good control will provide assurance to management to achieve organizational goals and objectives. If the goals and objectives of the organization have been achieved, it will improve the managerial performance by itself. Internal control has a positive influence on agency performance. Based on Usman's research (2013), it showed that the internal control system has a positive and significant impact on company performance at PT MNC Sky Vision Branch Gorontalo with determination coefficient of $40.2 \%$.

The results of research by Puspitasari, et.al. (2015) and Taylor (2014) showed that organizational culture with the implementation of a good organizational culture needed to provide a good corporate image to employees and wider community, because it is an identity that can describe a company and distinguish one company 
to another. While the results of research by Soleman (2012) and Indrawati (2017) showed that the interaction of organizational culture categorized weak means negatively affect the managerial performance. Both of these studies produced contrasting results. On one hand, organizational culture has an influence on employee performance and on the other hand organizational culture with participative budgeting has a negative effect on managerial performance. From research conducted by the researchers, the authors are interested to conduct research on Banyumas Regency Work Unit regarding the impact of the implementation of internal control and organizational culture on managerial performance of government.

The hypotheses in this research are: (1) Internal control has significant effect on managerial performance of Banyumas Regency government; (2) There is a significant influence of organizational culture on managerial performance of Banyumas Regency government (Study on SKPD of Banyumas Regency); (3) There is a significant influence of internal control and organizational culture simultaneously on managerial performance of Banyumas Regency government (Study on SKPD of Banyumas Regency).

\section{METHOD}

This research was descriptive which aimed to describe thoroughly and clearly about the characteristics of problems or phenomena encountered, and a verificative research was a type of research that aimed to determine the relationship between variables through a hypothesis testing. The method used was explanatory survey that was done to obtain description systematically, factual and accurate about fact, nature of character and relationship between variables studied. The reason for the researcher to choose explanatory survey method was because the researcher wanted to find the answer fundamentally about causation by analyzing the factor that caused a certain phenomenon, which related to problems and practices in this research.

The variables in this study are presented in Table 1.

Table 1. Operationalization of Variable

\begin{tabular}{|c|c|c|c|c|}
\hline \multicolumn{5}{|c|}{ Independent Variable $\left(\mathrm{X}_{1}\right)$} \\
\hline Variable & Variable Indicator & Measurement Scale & Data Source & Analysis Tool \\
\hline $\begin{array}{l}\text { Internal Control }\left(X_{1}\right) \\
\text { According to Regent } \\
\text { Regulation No. } 64 \text { of } \\
2010\end{array}$ & $\begin{array}{l}\text {-Environmental Control } \\
\text {-Risk Assessment } \\
\text {-Control Activities } \\
\text {-Information and Communication } \\
\text {-Monitoring Internal Control }\end{array}$ & Interval & Primary & $\begin{array}{l}\text { Classic assumption } \\
\text { test, coefficient of } \\
\text { determination, multiple } \\
\text { linear regression, t test, } \\
\text { and } F \text { test }\end{array}$ \\
\hline $\begin{array}{l}\text { Organizational culture } \\
(\text { Stephen Robbins))* }\end{array}$ & $\begin{array}{l}\text {-Individual Initiative } \\
\text {-Tolerance of risky action } \\
\text {-Briefing } \\
\text {-Integration } \\
\text {-Management Support } \\
\text {-Control } \\
\text {-Identity } \\
\text {-Rewards System } \\
\text {-Tolerance toward conflicts } \\
\text {-Communication Patterns }\end{array}$ & Interval & Primary & $\begin{array}{l}\text { Classic assumption } \\
\text { test, coefficient of } \\
\text { determination, multiple } \\
\text { linear regression, t test, } \\
\text { and } F \text { test }\end{array}$ \\
\hline $\begin{array}{l}\text { Managerial Performance } \\
\text { according to Malcolm } \\
\text { Bridge)** }\end{array}$ & $\begin{array}{l}\text {-Leadership } \\
\text {-Strategic Planning } \\
\text {-Customer and public services } \\
\text {-Measurement, analysis, } \\
\text { and application of science in } \\
\text { management } \\
\text {-Empowerment of human resources } \\
\text {-Management Process } \\
\text {-Organizational results }\end{array}$ & Interval & Primary & $\begin{array}{l}\text { Classic assumption } \\
\text { test, coefficient of } \\
\text { determination, multiple } \\
\text { linear regression, } t \text { test, } \\
\text { and } F \text { test }\end{array}$ \\
\hline
\end{tabular}


Likert scale was used to measure the attitude of respondents by using scoring $/ 5$ scale as follows: Strongly Agree (SA), Agree (A), Neutral (N), Disagree (S) and Strongly Disagree (SD). The population of this research is 84 SKPD in Banyumas Regency consisting of heads of departments, heads of agencies, secretariats, hospitals, sub-districts and urban communities. Samples taken were 46 SKPD. Sampling of 46 SKPD were based on Slovin method.

Testing instrument used are validity test and reliability test. To analyze the influence between internal control $\left(\mathrm{X}_{1}\right)$ and Organizational Culture $\left(\mathrm{X}_{2}\right)$ on Managerial Performance (Y), the author used multiple regression analysis technique. The reason for the using of multiple regression analysis in this study was because independent variables amounted to more than one, which were two variables. The analysis used multiple regression equation model.

\section{RESULTS}

The study was conducted at the Regional Work Unit (SKPD) in Banyumas Regency by distributing questionnaires, conducting interviews and observations in the SKPD area on May 23 to June 23, 2016. Interviews and observations indicated that in an effort to improve public services, Banyumas Regency developed several government support technologies, such as SKPD website, e-Office, Satria Keuangan, and face-finger technology. Development of technology was expected to facilitate and accelerate the work of the government, with the SKPD website, information about Banyumas could be accessed easily. The implementation of e-Office aimed to facilitate the office work, especially the correspondence handler and the management of the official note, Satria Keuangan was expected to be buds for the development of integrated financial management information system and face finger served as an electronic attendance that was expected to improve discipline.

Organizational culture that applied among work culture was SATRIA, humble culture of civil servants, clean culture, and many others. The application of organizational culture was expected to create attitudes, behaviors, and work environments that support the achievement of the motto of Banyumas SATRIA, meaning able to improve the spirit and work productivity, and able to improve the quality of public service of Banyumas Regency government apparatus.

From the implementation of internal control and organizational culture, Banyumas local government has ranked and reached various achievements such as Unqualified Predicate 5 times consecutively during 2011-2015, Adipura award during 2014-2015, and rewards of course and training year 2014. From the description of the implementation of internal control and organizational culture within the scope of Banyumas, local government indicated that internal control and organizational culture had a significant influence on managerial performance of government especially in the scope of Banyumas Regency SKPD. Details of receipt and return of questionnaires are shown in Table 2.

Table 2. Details of Reception and Return of Questionnaire

\begin{tabular}{lc}
\hline \multicolumn{1}{c}{ Description } & Result \\
\hline Total Questionnaire distributed & 46 \\
Total Questionnaire returned & 43 \\
Total Questionnaire not taken & 3 \\
Rate of Return & $93 \%$ \\
Incomplete Questionnaire & 0 \\
Total Questionnaire that can be processed & 43 \\
Rate of Returned Questionnaire that can be used & $100 \%$ \\
\hline Source Processed Data
\end{tabular}

Source : Processed Data

Out of 46 research questionnaires distributed in SKPD of Banyumas Regency, only 43 questionnaires were successfully received and eligible to be used in the next research process. Result of validity and reliability test showed valid and reliable questionnaire. Test result of normality of data was done by using Kolmogorov Smirnov test, showing data followed normal distribution.

The result of the research analysis with multiple linear regression is shown in Table 3.

Tabel 3. Hasil Perhitungan Regresi Linier Berganda

\begin{tabular}{lrlcc}
\hline \multicolumn{1}{c}{ Variabel } & Koef Regresi & $\mathrm{t}_{\text {hitung }}$ & $\mathrm{t}_{\text {tabel }}$ & \multicolumn{1}{c}{ Sig. } \\
\hline Konstanta & 21,104 & 2,675 & 2,01954 & 0,010 \\
$\begin{array}{l}\text { Pengendalian } \\
\text { Intern }\end{array}$ & 0,447 & 4,980 & 2,01954 & 0.000 \\
Budaya & & & & \\
Organisasi & $-0,118$ & $-0,720$ & 2,01954 & 0,471 \\
\hline & $\mathrm{R}$ & $=0,709$ \\
& Rsquare & $=0,503$ \\
& Standar Error & $=3,56704$ \\
& Fhitung & $=20,241$ \\
& Fsig & $=0,000$ \\
& $\mathrm{~N}$ & $=43$ \\
\hline
\end{tabular}

Source : Processed Data

The linear regression equation with 2 predictors is as follows:

$$
Y=21,104+0,447 X_{1}-0,118 X_{2}+e
$$

Where:

$\mathrm{Y}=$ Quality of Financial Statement

$\beta_{0}=$ The coefficient of intercept (constant), i.e. value $Y$ if the value of all other variables is zero

$\beta_{1}=$ Regression coefficient of variable $\mathrm{X}_{1}$ 
$\beta_{2}=$ Regression coefficient of variable $X_{2}$

$\mathrm{X}_{1}=$ Internal Control

$\mathrm{X}_{2}=$ Organizational Culture

$\varepsilon=$ Error term from other variables

The simultaneous test result is shown in Table 4.

Tabel 4. Hasil Uji F

\begin{tabular}{llccccc}
\hline Model & & $\begin{array}{c}\text { Sum of } \\
\text { Squares }\end{array}$ & df & $\begin{array}{c}\text { Mean } \\
\text { Square }\end{array}$ & F & Sig. \\
\hline 1 & Regression & 515.094 & 2 & 257.547 & 20.241 & $.000^{\mathrm{b}}$ \\
& Residual & 508.952 & 40 & 12.724 & & \\
& Total & 1024.047 & 42 & & & \\
\end{tabular}

a. Dependent Variable : KM4

b. Predictors : (Constant), BD, SPI11

Based on the simultaneous test result, internal control and organizational culture simultaneously have a significant influence on managerial performance of government. Based on the result of partial test shown in Table 3, it can be seen that internal control partially has significant influence to the managerial performance of government.

The calculation of the coefficient of determination is shown in Table 5.

Table 5. Calculation Result of Coefficient of Determination

\begin{tabular}{lrrrr}
\hline Model & $\mathrm{R}$ & $\begin{array}{c}\mathrm{R} \\
\text { square }\end{array}$ & $\begin{array}{r}\text { Adjusted R } \\
\text { Square }\end{array}$ & $\begin{array}{r}\text { Std. Error of } \\
\text { The Estimate }\end{array}$ \\
\hline 1 &, $0709^{\mathrm{a}}$ &, 503 &, 478 & 3,56704
\end{tabular}

a. Predictor: (Constant), Organizational Culture, Internal Control

b. Dependent Variabel : Managerial Performance

The calculation result of coefficient of determination shows that $R$ equal to 0.709 with $R$ Square value equal to 0.503 which means the magnitude influence of Internal Control and Organizational Culture on Managerial Performance of Government of Banyumas Regency is equal to $50.3 \%$. Whereas, $49.7 \%$ is another factor influencing the managerial performance of government which is not discussed in this research.

\section{DISCUSSION}

The results of this study supported the results of research by Andriyanto (2013), Nazir \& Oktani (2011), Usman (2013) that internal control has a significant influence on managerial performance of government. From the results of interviews that had been conducted and observations on SKPD environment, it can be concluded that the controls carried out by the structural line of government both in the urban communities and in the sub-districts have been done well. Starting from the discipline control of employees who have used facefinger technology, daily assembly activities, document control both financial and non-financial documents manually (hardcopy) and computerized (softcopy) in most SKPD were neat and well organized.

Organizational culture partially has no significant effect on managerial performance of the government, because the organizational culture is an activity that is applied by an organization that is required by the rules and not a thing that appears by itself and become a habit. The results of this study are in line with the research by Soleman (2012) which explains the weakness of organizational culture in bureaucracy caused by organizational culture is monopoly. Therefore, it tends not to have any consequences for the performance so the role of bureaucracy people tend to think more about budget and rank rather than thinking about ways to improve results.

This result does not support the research by Soleman (2012) which shows no effect of participative budgeting on managerial performance with organizational culture as moderating variable. The reason for the difference of research results is because the form of internal control variables in this study is a free variable that affects the dependent variable. While in Soleman's research, organizational culture is merely a moderating variable or variable that supports the relationship between one variable with another.

Internal control by Banyumas Regency government can function effectively when it is implemented inherent with the operational activities of the organization and is part of organizational culture, able to respond quickly to the risks arising in the implementation of government activities. In other words, when the government's operational activities have run smoothly, the internal control has done optimally. Coupled with the implementation of organizational culture that is working culture, SATRIA expected to create attitude, behavior, and work environment that support the achievement of Banyumas SATRIA motto, able to improve the spirit and work productivity, and able to improve the quality of public services Banyumas local government apparatus. With the achievement of internal control objectives and the culture of government organizations, they can altogether affect the managerial performance of the Regency government of Banyumas.

Based on the result of $t$ test, internal control has significant influence to the managerial performance of Banyumas regency government. The results of this study support the results of research by Andriyanto (2013), Nazir and Oktani (2011), Cecilia and Afiah (2017), and Usman (2013) that internal control has a significant influence on managerial performance of government. From the results of interviews that had been conducted and observations on SKPD environment, it can be concluded that the controls carried out by the structural line of government both in the urban communities and in the sub-districts has been done well. Starting from the discipline control of employees who have used face- 
finger technology, daily assembly activities, document control both financial and non-financial documents manually (hardcopy) and computerized (softcopy) in most SKPD were neat and well organized.

Then viewed from the theoretical side, internal control aims to provide adequate confidence for the achievement of effectiveness and efficiency in achieving the objectives of the administration of state governments, reliability of financial reporting, security of state assets, and compliance with laws and regulations. This is reinforced by the implementation of internal controls in SKPD Banyumas Regency that has been implemented properly and in accordance with the objectives of internal control contained in the 2008 Government Regulation no. 60 on internal control system of the government.

The result of $t$ test shows that organizational culture has no significant effect on managerial performance. The minus sign indicates that the organizational culture has the opposite relationship to the Beta direction. The results of this study indicate differences in terms of the theory described in the work of T.0 Peters and R.H Waterman (Mulyadi, 2015:98) that organizational culture is one of the key factors of organizational success. This indicates that although organizational culture is a key factor of organizational success, it has no significant effect on managerial performance of government applied. This is because the organizational culture is an activity that is applied by an organization that is required by the rules and not a thing that appears by itself and become a habit. Therefore, the application of organizational culture within the scope of Banyumas Regency SKPD is the work culture of SATRIA and other cultures based on a rule.

The results of this study are in line with the research of Soleman (2012) which explains the weakness of organizational culture in bureaucracy caused by organizational culture is monopoly so it tends not to have any consequences for the performance. Therefore, the role of bureaucracy made people tend to think more about budget and rank rather than thinking about ways to improve results.

The result of $F$ test shows that there is significant influence of internal control and organizational culture on managerial performance of government. This result does not support the research of Soleman (2012) which indicates the absence of influence of participative budgeting on managerial performance with organizational culture as moderator variable and Indrawati's research (2017) which revealed that there is no influence of organizational culture on the improvement of managerial performance. The reason for the difference of research results is because the form of internal control variable in this study is an independent variable that affects the dependent variable. While in Soleman's research, organizational culture is merely a moderating variable or variable that supports the relationship between one variable with another, and in Indrawati's research using intervening variable that is New Public Management Implementation.

\section{CONCLUSION}

The results showed that internal control has a significant influence, while organizational culture has no significant effect on managerial performance of the government. Simultaneous test result shows that internal control and organizational culture simultaneously have a significant influence on managerial performance of government.

The results of research on SKPD of Banyumas Regency indicate that internal control and organizational culture have been implemented well. Improving the application of internal control and organizational culture will improve the managerial performance of the government of Banyumas Regency. It should always be improved with evaluation and improvement because there are still shortcomings both in terms of individual employees as well as from techniques of implementing activities of internal control and organizational culture. Leaders and staff must be able to conduct internal control activities together.

\section{REFERENCES}

Andriyanto, Nova. 2013. Pengaruh Pengendalian Intern dan Penerapan Prinsip Good Corporate Governance Terhadap Kinerja Manajerial (Studi empiris pada PT BRI (Persero) Tbk Cabang Jember). Jember: Jurusan Akuntansi Fakultas Ekonomi S1 Universitas Jember

Cecilia, Nunuy NurAfiah. 2017. Pengaruh penganggaran partisipatif, kelejasan anggaran, sasaran anggaran dan implementasi pengendalian internal terhadap kinerja manajerial instansi pemerintah daerah serta implikasinya pada akuntabilitas keuangan, SNAB Proceedings ISSN-2252-3936

Doyle, J., Ge, Weili, Mc Vay, S. 2007. Determinant of Weaknesses in Internal Control Over Financial Reporting. Journal of accounting and Economics, 44, 193-223

Hazmi \& Zuarni. 2012. Pengaruh Kesulitan Anggaran terhadap Kinerja Manajerial Sektor Publik dan Partisipasi penganggaran sebagai variabel moderasi. Riau: E-journal FE Universitas Riau, Vol 19(2)

Indrawati, Lili. 2017. Peran Budaya Organisasi terhadap implementasi New Publik manajemen dalam peningkatan Kinerja Manajerial Sektor Publik.Bandung: jurnal Ekspansi Jurnal ekonomi, keuangan, perbankan dan akuntansi. Vol 9 no 2 Nopember 2017.

Jianfeileng, Pangjing Zhao. 2013. Study on the impact of the quality of internal control on the performance of M\&A, JSSM, Vol 6 No 3, august 2013 
Nasir, Azwir dan Ranti Oktari. 2011. Pengaruh pemanfaatan teknologi informasi dan pengendalian intern terhadap kinerja instansi pemerintah (Studi pada Satuan Kerja Perangkat Daerah Kabupaten Ngampar). Riau: E-journal FE Universitas Riau, Vol 19(2)

Petrovits, Christine, Shakespeare, Chaterine, dan Shih, Aimee. 2010. The Causes and Consequences on Internal Control Problems in Nonprofit Organizations. Available at SSRN: https://ssrn.com/ abstract $=1582765$ or http://dx.doi.org/10.2139/ssrn.

Puspitasari, Devi Dwike dkk. 2015. Pengaruh Budaya Organisasi, Pelatihan, dan Komunikasi terhadap kinerja karyawan pada PT KAI (Persero) Tbk. Surabaya: Jurnal Manajemen BRANCHMARCK Fakultas Ekonomi

Rusman Soleman, 2012. Pengaruh penganggaran partisipatif terhadap kinerja manajerial dengan budaya organisasi dan gaya kepemimpinan sebagai variable intervening, Siasat Bisnis Vol 16 No 1 Januari 2012.

Taylor, Jeanette. 2014. Organizational Culture and the paradox of Performance Management, public performance \& Management Reviewer, vol 38, 2014-issue 1.

Testa, M. R. \& Sipe, L. J. 2013. The Organizational Culture Audit: Countering Cultural Ambiguity in the Service Context. Open Journal of Leadership, $2(02), 36$.

Usman, Zulkarnain. 2013. Pengaruh Sistem Pengendalian Intern terhadap Kinerja Perusahaan pada PT MNC Sky Vision Cabang Gorontalo. Gorontalo: Prodi S1 Akuntansi Universitas Negeri Gorontalo 